\title{
Hanged from a Yardarm
}

\author{
A Historical Analysis of Richard Parker's \\ 1797 Trial and Execution
}

AUTHOR: Andrew Johnston

EDITED BY: Esti Azizi and Marisa Coulton

'Black, bloody mutiny' was the ultimate crime in the Royal Navy of the age of sail. Defined by the Oxford Companion to Ships and the Sea as "resistance by force to recognized authority ... in any naval or military force of a nation," mutiny was the most serious crime a sailor, of any rank, could commit in the Royal Navy for much of its history. ${ }^{1}$ This would have been well known by Richard Parker - sailor, schoolteacher, and unofficial leader of the Nore mutiny of May and June 1797. He knew that the moment the red flag was raised by the fleet at the Nore his life would be in danger. ${ }^{2}$ Perhaps he drew solace from the pardons issued following the previous month's mutiny at Spithead, or perhaps he truly believed in his ability to negotiate a peaceful settlement from the admiralty. However, Richard Parker had to die. Regardless of the legitimacy of the demands of the Nore mutineers, too many forces were arrayed against Parker and his colleagues to ensure success. While only one of twenty-nine to hang at the Nore, Parker's role as "President of the Floating Republic" made him a figurehead, and the historical precedent of mutiny trials in the Royal Navy ensured that he would hand before the admiralty and a system of naval justice that made England's "Bloody Code" look positively humane.

The first iteration of the Articles of War, the infamous code of naval law, appeared in 1661 during the reign of Charles II. Nearly all offences carried the punishment of death, and only the most minor crimes permitted any form of leniency. ${ }^{3}$ This prevented any discretion by the court-martial for the more serious offences. Article nineteen, one of the shortest in the 1661 Act, states clearly that those who attempted sedition or mutiny would suffer death. ${ }^{4}$ For legislative and legal simplicity, the Articles were amalgamated in 1749 under George II, but remained largely the same. ${ }^{5}$ The final changes to the articles prior to the French Revolutionary Wars occurred in 1779, with the Naval Courts-Martial Act. The sole purpose of this act was to introduce additional, although limited, discretionary powers to the court-martial, allowing for more leeway in the case of high-profile trials. ${ }^{6}$

Excepting the 1779 'reforms,' the Articles of War remained virtually unchanged from their original 1661 state at the time of the mutinies of Spithead and the Nore. While no 'official' reforms had occurred during the period, most admirals, captains, and courts-martial made full use of their limited discretionary powers, and by 1800 , only two of the navy's eight technically capital offences usually carried a death sentence: murder and mutiny. ${ }^{7}$ Discretion had been fully employed to prevent the needless sacrifice of valuable sailors during times of war. The only offences where the death penalty was still usually enforced were those that threatened naval manpower, either directly through murder, or indirectly through sedition and mutiny. ${ }^{8}$ Alongside punishments such as "running the gauntlet"9 or "flogging 'round the fleet,"10 this perfectly exemplifies the 'eye for an eye' mentality that remained the crux of naval crime and punishment, long after criminal legal theory had evolved, and it was this same theory that governed the actions of the court at the Nore. 
Although courts-martial were required to enforce the death penalty for mutiny, mutineers who never came before court-martial often kept their lives. In Command of the Ocean, N.A.M. Rodger argues that the Great Mutinies of Spithead and the Nore cannot be fully appreciated in a vacuum, and to fully understand the importance of Spithead and the Nore, one requires a knowledge of the more typical mutinies that occurred in the Royal Navy during this period. ${ }^{11}$ The typical mutiny, according to Rodger, rarely involved more than a single ship, and were usually over relatively minor grievances, such as a harsh punishment for swearing. ${ }^{12}$ Oftentimes, such mutinies were settled directly between the mutinous crews and their officers, never coming before a court-martial, usually leading to lighter punishments (if any) for those involved. ${ }^{13}$ Of course there were exceptions, such as the incredibly violent mutiny on H.M.S. Hermione or the even more famous mutiny on the Bounty, but these were as atypical from the 'standard' mutiny as were Spithead and the Nore. ${ }^{14}$

The rarity of the mutiny at Spithead, often referred to as the "Great Mutiny," came not only from its scale, but also its outcome. Occurring in April and May of 1797, the mutiny originated within the Channel Fleet at Spithead, an anchorage near Portsmouth, and eventually spread to fifteen ships. Several days following the outbreak, sixteen ships anchored at Plymouth joined the mutiny in support. ${ }^{15}$ The grievances of the Spithead mutineers came down to two main issues - pay and leave. ${ }^{16}$ Pay rates for ordinary seamen had not increased since the seventeenth century, and significant inflation in the late eighteenth century had further undermined the sailor's wages. In addition, the coppering of ships' hulls in the late eighteenth century greatly lengthened the duration of voyages, reducing the amount of shore leave sailors received, further heightening tensions. ${ }^{17}$ Despite its size, the Spithead mutiny was remarkably well organized and disciplined. Not only were most officers permitted to remain in their roles during the mutiny, but individual ships were permitted to engage in their normal duties. The only stipulation imposed by the Spithead delegates was that the whole of the Channel Fleet would not sail until their demands were met. That said, they were prepared to suspend the mutiny indefinitely in response to a significant French attack or invasion attempt. ${ }^{18}$ With the exception of a few minor "incidents," the negotiations proceeded quite smoothly, and the mutineers received very favorable terms from Admiral Lord Howe. These included a pay raise, reassignment of unpopular officers, and a Royal Pardon for all those involved. ${ }^{19}$ However, these concessions were negotiated out of necessity, and the admiralty had little patience remaining for dealing with any further demands of their sailors. This mindset is crucial to the understanding of the radically different response to the mutiny at the Nore.

Lord Howe's terms were not satisfactory for all, and another mutiny broke out at the Nore (an anchorage in the Thames estuary) in May 1797, continuing into June. Despite forceful attempts to maintain unity among the mutineers, the Nore mutineers did not have the cohesion of their contemporaries at Spithead, and their stricter demands were less likely to be accepted by the admiralty. ${ }^{20}$ In addition, the Nore anchorage served as a holding area for individual ships, and very few of the twenty-six ships that eventually took part in the mutiny had any previous association with each other, leading to a more fragmented affair than that at Spithead. ${ }^{21}$ Despite the severity of the complaints at Spithead, those at the Nore were forced to live in even more horrible conditions. H.M.S. Sandwich, a 90-gun second rate ship of the line and unofficial flagship of the ships at the Nore, had so many attached supernumeraries ${ }^{22}$ that the ship's doctor wrote the captain complaining about the horrid living conditions, even by naval standards. ${ }^{23} \mathrm{~A}$ minor outbreak of sedition on the Inflexible led to the summoning of a court-martial and once Admiral Buckner and Captain Moss left the ship to attend the proceedings, the crew took the opportunity to expel the first lieutenant, beginning the mutiny. ${ }^{24}$ Moss returned and attempted to settle the matter quietly, but was unsuccessful. Through parades, 
demonstrations, and the flying of the red flag, the mutineers quickly showed a capacity for unrest and violence those at Spithead had not exhibited, further antagonizing a hostile admiralty and a population terrified of the prospect of a French invasion. ${ }^{25}$

Richard Parker's rise to prominence among the delegates of the Sandwich was rapid but not surprising. Born in Exeter, Parker apprenticed to a navigator at the age of twelve and served on several ships of the Royal Navy, eventually rising to Master's mate and acting Lieutenant. ${ }^{26}$ As a midshipman on the Assurance, he was goaded into a confrontation with a senior officer, court-martialed, and disrated. Discharged in November 1794 due to ill health, he served as a schoolteacher in Scotland for a time. In 1797, he signed on to the Sandwich to help pay his debts. With his background as a petty officer and teacher, he was a well-educated man in both naval and civilian affairs and a natural leader among the crew of the ship. Having suffered the squalor of the Sandwich, albeit for only a short while, Parker was more than willing to join the mutiny's leadership when they approached him. ${ }^{27}$ This willingness would not have gone unnoticed during his subsequent trial.

With the crew of the Sandwich leading the mutiny and Parker the most prominent among them, he eventually arose to the position of "President of the Delegates of the Fleet."28 As president, it was his responsibility to communicate with the outside world, and nearly all the correspondence between the mutineers and the admiralty carried the signature "Richard Parker, President." 29 This made him known to the admiralty (and eventually the public) in a manner that would prove impossible to escape during his trial. Additionally, the mutineers' demands presented by Parker to Admiral Buckner were more extensive than those at Spithead. Some were related to pay, leave, or other matters which had be dealt with at Spithead and received Buckner's wholehearted approval. ${ }^{30}$ Others, however, demanded that the ordinary seamen have more say in the day-to-day functioning of the navy, with article eight demanding a very comprehensive overhaul of the articles of war. ${ }^{31}$ Having just recently acknowledged the demands of the Spithead mutineers, the admiralty was "shocked at the ingratitude of the sailors," 32 and this response led to escalation of the mutiny, leading to further violence and an attempted blockade of merchant traffic on the Thames. ${ }^{33}$ Parker was able to talk down many of the more radical mutineers before further violence broke out, but by early June it was clear that the mutiny had failed. Many of the more ringleaders fled, but as the mutiny began to break up a group of loyal officers and men arrested Parker on the Sandwich. He was court-martialed on June 22, 1797.

The trial of Richard Parker was one of the most publicised in navy history, with copies of the trial record still being sold. Newspapers all across the British Isles had published the story of the mutiny and trial by the end of June. ${ }^{34}$ Official histories of the Spithead and Nore mutinies, heavily featuring the Parker's trial, circulated extensively over the next half-century. ${ }^{35}$ Tried aboard the Neptune, Parker's court-martial was chaired by Admiral Sir Thomas Pasley, and a "jury" of twelve captains from ships not involved in the mutiny. ${ }^{36}$ Prosecuted by Captain Moss of the Sandwich, the trial proceeded in a very orderly manner, not overly dissimilar to a criminal trial in a civilian court, but for two major exceptions.

Most notably, the court-martial was much longer than the average criminal trial. Lasting (with weekend adjournment) from Thursday, June $22^{\text {nd }}$ to Monday, June $26^{\text {th }}$, a three-day trial would have been virtually unheard of in the criminal courts of the day. ${ }^{37}$ As evident from the trial record, the length was due primarily to the vast number of witnesses called by the court, the prosecutor, and the prisoner. Many of the witnesses were the senior officers of the ships at the Nore, such as Admiral Buckner, but there were also many petty-officers and ordinary seamen sworn in. ${ }^{38}$ Their examination took up most of Thursday and Friday even though many witnesses were rejected, stating they did not know the prisoner. ${ }^{39}$ Declaring that it would be impossible for him to prepare his case by Saturday, 
Parker was granted both Saturday and Sunday to organize his defence and was presented with "paper, pens, ink, ... and what was necessary" to do so. ${ }^{40}$ According to the record, Admiral Pasley reminded Parker that he was "detaining a vast number of people ... who are wanted for the service of their country," 41 further emphasising the unusual length of Parker's court-martial. When the trial resumed the following Monday, Parker was pleasantly surprised by the news that the courtmartial saw fit to summon several men of the Nore fleet "for the prisoner to call [as witnesses] if he should think proper." 42 Parker's defence focused on the fact that he was not among the group that had first initiated the mutiny, and was unable to refuse the responsibility when it was thrust upon him. ${ }^{43}$ However, given his previous failure in the navy and rapid elevation within the ranks of the mutineers, many at the time believed that Parker had returned to the navy solely for the purpose of fermenting sedition and mutiny. ${ }^{44}$ Although it is impossible to deny that the circumstances suggested this as a very likely motivation for Parker's actions, there is no evidence that Parker knew anything of the mutiny until after it had already begun..$^{45}$ Regardless of the evidence supporting Parker's claims that he had attempted to calm the mutiny and had no part in its outbreak, his significant and highly-visible role in the mutiny meant that the court-martial had no choice but to condemn him to death following three hours of deliberation. ${ }^{46}$

The other major difference between Parker's court-martial and contemporary criminal trials was the composition of the court itself. William Neale, in his 1842 History of the Mutiny at Spithead and the Nore, argued that "the felon that commits ... the most savage of murders, can only be tried by twelve of his equals." 47 Unlike felony trials, where the accused was tried by a jury of twelve of their (relative) social equals, the court-martial at the Nore comprised of Admiral Pasley and a panel of twelve captains. ${ }^{48}$ Although (at least in theory) these captains had no connections to their counterparts at the Nore and were supposedly impartial, the upper echelons of the navy were a very close-knit group, and inevitably the jurors and the deposed captains of the Nore had some social connections to one another. ${ }^{49}$ In addition, as the crime of mutiny struck the very heart of naval discipline and authority, these captains would have had a vested interest in quelling mutineers wherever they arose. ${ }^{50}$ Finally, these captains were by no means the social equals of Parker, as several held knighthoods and peerages. ${ }^{51}$ Regardless of the difficulties facing Parker in a martial rather than a criminal court, Neale maintained that Parker was still presented with a just trial, due to the "fairness and humanity" of Admiral Pasley and his jury. ${ }^{52}$ Many of the criticisms Neale made against the process of the courtmartial, such as the lack of defence counsel, were not valid given the time; the Prisoner's Counsel Act, guaranteeing that right, would not be passed for another forty years. ${ }^{53}$ However, as evident in the court record, every courtesy that an accused mutineer could expect was shown to Parker during the trial. ${ }^{54}$ Unfortunately for Richard Parker, this included the sentence as well.

The King's Proclamation of May 31, 1797 echoed what he and many of his ministers and admirals believed - that the mutiny at the Nore was little more than a defiant rejection of the "gracious intentions and declarations" offered by Act of Parliament to those at Spithead, and the asking of even greater reform was simple greed on behalf of the mutineers. ${ }^{55}$ Some even viewed their demands as politically destabilizing, putting additional pressure for a conviction on the courtmartial. ${ }^{56}$ Of the companies of the twenty-six ships that eventually took part in the mutiny, 412 sailors were court-martialled. Of those, fifty-nine were sentenced to death, nine flogged (ranging from forty to 380 lashes), and twenty-nine imprisoned. Half those sentenced to death were pardoned on various terms, with at least one on condition of transportation for life. Twenty-nine, including Parker, were hanged. ${ }^{57}$ Although a surprisingly large proportion of the Nore mutineers were pardoned, the violence and timing of the mutiny meant that a scapegoat was necessary, and thus, at least some of the accused had to die, Parker 
included.

Despite his lack of legal counsel, Parker's speech in self-defence was remarkably eloquent, as were the testimonies of his witnesses. He defended the "consciousness of the integrity of [his] intentions with respect to the mutiny," claiming that he "entered into [the mutiny] solely with the view of repressing the dangerous spirit [he] saw predominant in the fleet." 58 Nevertheless, his role in the Nore mutiny was too visible and disruptive to escape unscathed. Regardless of his role in the mutiny's outbreak, Parker's role as president ensured he would hang before a court that treated mutineers as the worst of all offenders, and with pressure from the highest echelons of society and the navy, Richard Parker was hanged aboard the Sandwich on June $30^{\text {th }}$, under the yellow flag of capital punishment.

\section{ENDNOTES:}

1. Peter Kemp, The Oxford Companion to Ships and the Sea (New York: Oxford University Press, 1988), 570.

2. A red flag was famously flown from the mutinous ships at the Nore, described as the "bloody flag of defiance." Although a red flag did not have ideological meaning in the $18^{\text {th }}$ century, it has been suggested that the presence of the red flag meant that the Nore mutineers were acting along class lines, in addition to their more direct grievances (Clair Anderson, Mutiny and Maritime Radicalism in the Age of Revolution). The red flag was also heavily used by pirates in the $16^{\text {th }}-18^{\text {th }}$ centuries, the French Jolie Rouge ("pretty red") being the etymological origin of "Jolly Roger." This is an important connection given Parker's conviction of piracy in addition to treason, although strangely not mentioned in the trial records.

3. "Charles II, 1661.

4. "Noe Person in or belonging to the Fleete shall utter any words of Sedition or Mutiny nor make or endeavour to make any mutinous Assemblies upon any pretence whatsoever upon pain of death." (Ibid., Article 19).
5. "George II, 1749.

6. "George III, 1779. The most famous example being the 1757 execution of Admiral Byng, who was court-martialled and executed following the loss of Minorca during the Seven Years' War. His crime was "failing to do his utmost to engage or destroy the enemy." N.A.M. Rodger, The Command of the Ocean: A Naval History of Britain, 1649-1815. (London: Penguin Books, 2004), 266-67.

7. Kemp, 570.

8. Kemp, 415.

9. The usual punishment for stealing, "running the gauntlet" or "gauntlope," allowed the entire ships' company to punish the guilty party by forcing the accused to walk between two rows of their shipmates as they beat them. It was abolished by admiralty orders in 1806. (Kemp, 338).

10. A very serious punishment, by which the accused would be flogged (upwards of twelve times) on every ship of the fleet. Depending on the size of the fleet in question, the prisoner would very often die from their wounds following (or even during) the punishment. (Kemp, 317).

11. Rodger, 444.

12. Ibid.

13. Ibid., 445.

14. For further reading on the Hermione and Bounty mutinies see Richard Woodman's A Brief History of Mutiny, chapters 5 and 8.

15. G.E. Manwaring. The Floating Republic.

(London: Frank Cass \& Co., Ltd., 1966), 71.

16. Manwaring, 44.

17. Ibid., 46.

18. Ibid., 66.

19. Nicholas Tracy (ed). The Naval Chronicle: The Contemporary Record of the Royal Navy at War: Volume I, 1793-1798. (London: Chatham Publishing, 1998), 210.

20. Manwaring, 141-143.

21. Kemp, 601.

22. The usual wartime complement of a Sandwich class second rate was roughly 750, but in 1797 HMS Sandwich had a total complement over twice that.

23. Manwaring, 123. 
24. Ibid., 127.

25. James Dugan. The Great Mutiny. (New York:

G.P. Putnam's Sons, 1965), 185.

26. "Parker, Richard (1767-1797)," Ann Veronica

Coats in Oxford Dictionary of National Biography,

ed. H. C. G. Matthew and Brian Harrison (Oxford:

OUP, 2004); online ed., ed. David Cannadine,

January 2008, http://www.oxforddnb.com.

proxy1.lib.uwo.ca/view/article/21333 (accessed

November 15, 2017).

27. "Parker, Richard (1767-1797)," Ann Veronica

Coats in Oxford Dictionary of National Biography.

28. Ibid.

29. Manwaring, 185.

30. Ibid., 142.

31. Ibid., 143.

32. Ibid., 144.

33. Tracy, 230.

34. Robert Allen. "Richard Parker, Alias Admiral

Parker," Caledonian Mercury (Edinburgh), June 12, 1797.

35. William Neale. History of the Mutiny at

Spithead and the Nore. (London: Ward, Lock and

Co., 1842).

36. Job Sibly, "The Trial of Richard Parker..."

(court-martial record, London: John Fairburn, 1797), 3.

37. Clive Emsley. Crime and Society in England 1750-1900. (New York: Routledge, 2013), 195.

38. Sibly, 14.

39. Ibid., 8.

40. Ibid., 24.

41. Ibid.

42. Ibid.

43. Ibid., 34.

44. Manwaring, 134.

45. Ibid., 135.

46. Sibly, 43.

47. Neale, 302.

48. Sibly, 3.

49. Rodger, 448.

50. Noel Mostert. The Line Upon a Wind: The Great War at Sea, 1793-1815. (New York: W.W. Norton \& Company, 2007), 237.

51. Sibly, 3.

52. Neale, 302.
53. Ibid., 303.

54. Sibly, 28-29.

55. George III, May 1797.

56. Manwaring, 147.

57. Ibid., 277.

58. Sibly, 30.

\section{BIBLIOGRAPHY:}

Primary Sources

Allen, Robert. "Richard Parker, Alias Admiral Parker," Caledonian Mercury (Edinburgh), June 12, 1797.

"Charles II, 1661: An Act for the Establishing Articles and Orders for the regulateing and better Government of His Majesties Navies Ships of Warr \& Forces by Sea.," in Statutes of the Realm: Volume 5, 1628-80, ed. John Raithby (s.l: Great Britain Record Commission, 1819), 311-314. British History Online, accessed November 15, 2017, http://www. british-history.ac.uk/statutes-realm/vol5/pp311314.

"George II, 1749: An Act for amending, explaining and reducing into one Act of Parliament, the Laws relating to the Government of His Majesty's Ships, Vessels and Forces by Sea. Anno $22^{\circ}$ Georgii II c.33. CAP. XXXIII. Records of William Loney, RN. Accessed November 15, 2017, http://www.pdavis.nl/NDA1749.htm.

"George III, 1779: An Act to explain and amend an Act, made in the Twenty-second Year of the Reign of his late Majesty King George the Second, intituled, An Act for amending, explaining, and reducing into one Act of Parliament, the Laws relating to the Government of his Majesty's Ships, Vessels, and Forces by Sea." Anno decimo nono Georgii III c.17. CAP. XVII. Records of William Loney, RN. Accessed November 15, 2017, http://www. pdavis.nl/NDA1779.htm. (Henceforth referred to as "1779 Articles"). 
George III, "By the KING, A PROCLAMATION, For the Suppression of the Mutinous and Treasonable Proceedings of the Crews of Our Ships at the Nore," London Gazette (London), May 31, 1797.

Sibly, Job. "The Trial of Richard Parker..." Courtmartial record, London: John Fairburn, 1797.

Tracy, Nicholas (ed). The Naval Chronicle: The Contemporary Record of the Royal Navy at War: Volume I (1793-1798). London: Chatham Publishing, 1998.

Neale, William Johnson. History of the Mutiny at Spithead and the Nore. London: Ward, Lock and Co., 1842.

\section{Secondary Sources}

Anderson, Clair. Mutiny and Maritime Radicalism in the Age of Revolution. Glasgow: Bell \& Bain Ltd., 2013.

Coats, Ann Veronica. "Parker, Richard (17671797)." Ann Veronica Coats in Oxford Dictionary of National Biography, edited by H. C. G. Matthew and Brian Harrison. Oxford: OUP, 2004. Online ed., edited by David Cannadine, January 2008. http:// www.oxforddnb.com.proxy1.lib.uwo.ca/ view/article/21333 (accessed November 15, 2017).

Dugan, James. The Great Mutiny. New York: G.P. Putnam's Sons, 1965.

Emsley, Clive. Crime and Society in England 1750-1900. New York: Routledge, 2013.

Grieve, Andrew, dir. Horatio Hornblower: The Mutiny. 2001; New York, NY: A\&E, 2001. DVD.

Kemp, Peter. The Oxford Companion to Ships and the Sea. New York: Oxford University Press, 1988.

Manwaring, G.E. The Floating Republic. London: Frank Cass \& Co., Ltd., 1966.

Mostert, Noel. The Line Upon a Wind: The Great War at Sea, 1793-1815. New York: W.W. Norton \& Company, 2007.

Rodger, N.A.M. The Command of the Ocean: A Naval History of Britain, 1649-1815. London: Penguin Books, 2004. 